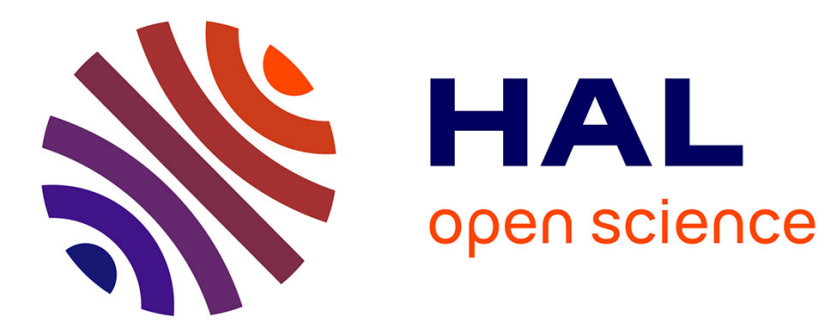

\title{
Wood-mineral wool hybrid particleboards
}

M. Ł. Mamiński, M. E. Król, W. Jaskólowski, P. Borysiuk

\section{To cite this version:}

M. Ł. Mamiński, M. E. Król, W. Jaskólowski, P. Borysiuk. Wood-mineral wool hybrid particleboards. European Journal of Wood and Wood Products, 2010, pp.337-339. 10.1007/s00107-010-0470-6 . hal00610737

\section{HAL Id: hal-00610737 \\ https://hal.science/hal-00610737}

Submitted on 24 Jul 2011

HAL is a multi-disciplinary open access archive for the deposit and dissemination of scientific research documents, whether they are published or not. The documents may come from teaching and research institutions in France or abroad, or from public or private research centers.
L'archive ouverte pluridisciplinaire HAL, est destinée au dépôt et à la diffusion de documents scientifiques de niveau recherche, publiés ou non, émanant des établissements d'enseignement et de recherche français ou étrangers, des laboratoires publics ou privés. 


\title{
Wood-mineral wool hybrid particleboards
}

\author{
M.Ł. Mamiński $(\bowtie)$, M.E. Król ${ }^{\mathrm{a}}$, W. Jaskółowskib ${ }^{\mathrm{b}}$, P. Borysiuk ${ }^{\mathrm{a}}$ \\ ${ }^{a}$ Warsaw University of Life Sciences - SGGW, Faculty of Wood Technology \\ 159 Noakowskiego St., 02-776 Warsaw, Poland \\ ${ }^{b}$ The Main School of Fire Service \\ 52/54 Stowackiego St., 01-629 Warsaw, Poland \\ *corresponding author: mariusz_maminski@sggw.pl
}

\begin{abstract}
The objective of this work was to compound mineral wool with wood particles in the production of particleboards of reduced flammability. Three series of boards with various contents of mineral wool $(10,20,30 \mathrm{wt} \%)$ were successfully manufactured using ureaformaldehyde resin as binder. Thickness swelling, mechanical and thermal properties as well as ignitability of the boards were assessed. It occurred that reduced ignitability is accompanied by a decrease in mechanical performance.
\end{abstract}

\section{Introduction}

There are several types of insulating materials commonly used in engineering. The three main groups of the boards used in house construction are: (1) natural wood-based materials like low density fiberboard, insulation board from kenaff, hemp or wood fiber; (2) synthetic foams (polystyrene or polyurethane) and (3) boards based on natural inorganic materials (glass wool or mineral wool). On the contrary to wood-based materials or synthetic foams, the main advantage of mineral wool, apart from excellent insulation properties, is its inflammability (Karamanos et al. 2008). 
EJWWP470_source

There are some reports on compounding wood material with mineral components - like vermiculite (Kozłowski et al. 1999), cement (Okino et al. 2005; Qi et al. 2006) or potassium aluminosilicate (Giancaspro et al. 2008).

In some applications low flammability of the materials accompanied by retention of mechanical properties is required. In such cases, the use of particleboards with reduced flammability seems to be reasonable. Thus, an attempt of hybrid wood - mineral wool boards manufacturing by compounding of mineral wool with wood particles was undertaken. In this paper some thermal, sorptive and mechanical properties of the manufactured boards were described.

\section{Materials and methods}

Three series of one-layer particleboards $\left(330 \times 330 \times 12 \mathrm{~mm}^{3}\right.$, density $\left.600 \mathrm{~kg} / \mathrm{m}^{3}\right)$ with 10,20 or $30 \mathrm{wt} \%$ on dry wood basis of mineral wool were prepared. The boards were made of industrial grade chips (6.0\% moisture content) and mineral wool (2.2\% moisture content). A commercial urea-formaldehyde (UF) resin was used as adhesive. Glue formulation: UF 50 parts by weight, $10 \%$ ammonium chloride 1.2 parts by weight, water 12 parts by weight. Glue rate $10 \mathrm{wt} \%$. Same boards without mineral wool were used as controls.

Compounding of the materials involved three steps: (1) shredding of the wool into small pieces (ca. 5-10 mm), (2) mixing of the wool with wood particles, (3) blending of the mixture with glue. Then, a mat was formed and pressed under the following conditions: platens temperature $180^{\circ} \mathrm{C}$, maximum unit pressure $2.5 \mathrm{MPa}$, time $291 \mathrm{~s}$. Prior to testing, the boards were conditioned at $20 \pm 2{ }^{\circ} \mathrm{C}$ and $65 \pm 5 \% \mathrm{RH}$ for 7 days.

The ignitability was tested according to EN ISO 11925-2, modulus of rupture (MOR) according to EN 310 and internal bond (IB) according to EN 319. Thickness swelling was measured according to EN 317 . Thermal conductivity and thermal capacity were analyzed on 
EJWWP470_source

an ISOMET 2140 heat transfer analyzer (Applied Precision) instrument. Density profiles were measured on an X-ray density analyzer DA-X (GreCon).

\section{Results and discussion}

During ignitability tests neither 15 nor 30 s flame application caused self-sustainable fire. At last, $120 \mathrm{~s}$ flame treatment occurred to be necessary for ignition and path smouldering onto samples. As indicated in Table 1, there is no difference between the length of the smouldering path of the control and the $10 \%$ series. Only $20 \%$ addition of wool affected and shortened smouldering path by $19 \%$, while $30 \%$ addition of wool reduced that parameter by $30 \%$ when compared to the controls. The reduction in ignitability is proportional to the content of the mineral component.

The values of thermal conductivity and thermal capacity measured for the studied boards are shown in Table 1 . The data indicate that as small as $10 \%$ content of wool did not alter significantly those parameters, however, $20 \%$ and $30 \%$ additions resulted in a stepwise decrease in thermal conductivity by $7 \%$, whilst changes in thermal capacity were monotonic and achieved $11 \%$ and $19 \%$, respectively, when compared to the controls. Having in mind that thermal conductivity for uncompressed mineral wool is $0.033 \mathrm{~W} / \mathrm{mK}$ and that wool within the board is somehow compressed, the effect of the resultant efficacy of insulating is reasonable. Unlike thermal properties, the highest modulus of rupture (MOR) and internal bonding (IB) values were observed for the controls. Thus, it is obvious that addition of wool resulted in a decrease in mechanical properties - MOR by $27 \%-65 \%$ and IB by $32 \%$ and $71 \%$ for $20 \%$ and $30 \%$ of wool, respectively. However, $10 \%$ addition of wool did not affect IB. The deterioration of mechanical performance is ascribed to the low cohesion of the wool domains within the board. It is worth noting that the density profiles of the hybrid boards and that of the control shown in Fig. 1 are very much alike which proves satisfying dispersion of wool 
EJWWP470_source

among wood particles, and that required density of a board can be achieved. Therefore, the proposed method of compounding was found efficient.

Table. 1

Fig. 1

Surprisingly, the obtained values of thickness swelling exhibited by $10 \%$-series were slightly reduced which can be explained by compensation of dimensional changes within the wool domains, so that overall swelling of the board was avoided. For the higher content of wool, the effect was overwhelmed by an intense overall swelling.

\section{Conclusion}

In summary it can be concluded that hybrid particleboards with $20 \%$ mineral wool exhibit improved insulating properties and reduced ignitability, which - unfortunately - are accompanied by a deterioration of the mechanical properties. The described approach based on typical particleboard preparation procedure allows for compounding of mineral wool with wood particles. However, for the improved performance of the resultant hybrid particleboards, degree of wool shredding and wool pieces dimensions as well as glue load and pressing parameters should be considered for future work. 
EJWWP470_source

\section{References}

EN 310 (1994) Wood-based panels - Determination of modulus of elasticity in bending and bending strength

EN 317 (1999) Particleboards and fiberboards - Determination of swelling in thickness after immersion in water

EN 319 (1999) Particleboards and fiberboards - Determination of tensile strength perpendicular to the plane of the board

EN ISO 11925-2 (2002) Reaction to fire tests -- Ignitability of building products subjected to direct impingement of flame -- Part 2: Single-flame source test

Giancaspro J, Papakonstantinou C, Balaguru P (2008) Fire resistance of inorganic sawdust biocomposite. Compos Sci Technol 68: 1895-1902

Karamanos A, Hadiarakou S, Papadopoulos AM (2008) The impact of temperature and moisture on the thermal performance of stone wool. Energ Buildings 40: 1402-1411 Kozlowski R, Mieleniak B, Helwig M, Przepiera A (1999) Flame resistant lignocellulosicmineral composite particleboards. Polym Degrad Stabil 64: 523-528,

Okino EYA, de Souza RM, Santana MAE, da S. Alves MV, de Sousa ME, Teixeira DE (2005) Physico-mechanical properties and decay resistance of Cupressus spp. cement-bonded particleboards. Cement Concrete Comp 27: 333-338

Qi H, Cooper PA, Wan H (2006) Effect of carbon dioxide injection on production of wood cement composites from waste medium density fiberboard (MDF). Waste Manage 26: 509515 
EJWWP470_source

Fig. 1 Density profiles of the studied boards

Abb. 1 Dichteprofile der untersuchten Platten 
EJWWP470_source

Table. 1 Selected properties of the hybrid boards studied

Tabelle 1 Ausgewählte Eigenschaften der untersuchten Hybridplatten

\begin{tabular}{|c|c|c|c|c|c|c|c|}
\hline $\begin{array}{c}\text { Wool } \\
\text { content }\end{array}$ & Density & $\begin{array}{c}\text { Smouldering } \\
\text { path length }\end{array}$ & $\begin{array}{c}\text { Thermal } \\
\text { conductivity }\end{array}$ & $\begin{array}{c}\text { Thermal } \\
\text { capacity }\end{array}$ & MOR & IB & $\begin{array}{c}\text { Thickness } \\
\text { swelling } \\
\text { after } \mathbf{2 4} \mathbf{h} \\
\text { soaking }\end{array}$ \\
\hline$[\mathbf{w t} \%]$ & {$\left[\mathbf{k g} / \mathbf{m}^{3}\right]$} & {$[\mathbf{c m}]$} & $\lambda[\mathbf{W} / \mathbf{m K}]$ & $\begin{array}{c}\mathbf{C p} \\
{\left[\mathbf{J} / \mathbf{m}^{\mathbf{3}} \mathbf{K}\right]}\end{array}$ & {$\left[\mathbf{N} / \mathbf{m m}^{2}\right]$} & {$\left[\mathbf{N} / \mathbf{m m}^{2}\right]$} & {$[\%]$} \\
\hline 0 & $597(18)$ & 13.5 & 0.144 & 0.765 & $10.9(0.9)$ & $0.31(0.03)$ & $36.1(5.0)$ \\
\hline 10 & $595(31)$ & 13.5 & 0.143 & 0.755 & $7.9(1.4)$ & $0.31(0.04)$ & $31.6(2.3)$ \\
\hline 20 & $596(32)$ & 11.0 & 0.134 & 0.680 & $6.4(0.8)$ & $0.21(0.03)$ & $39.6(6.0)$ \\
\hline 30 & $570(42)$ & 9.5 & 0.133 & 0.619 & $3.8(0.7)$ & $0.09(0.01)$ & $49.1(9.1)$ \\
\hline
\end{tabular}

$*$ Values in parentheses are standard deviations. $* * \lambda$ for mineral wool is $0.033 \mathrm{~W} / \mathrm{mK}$. 


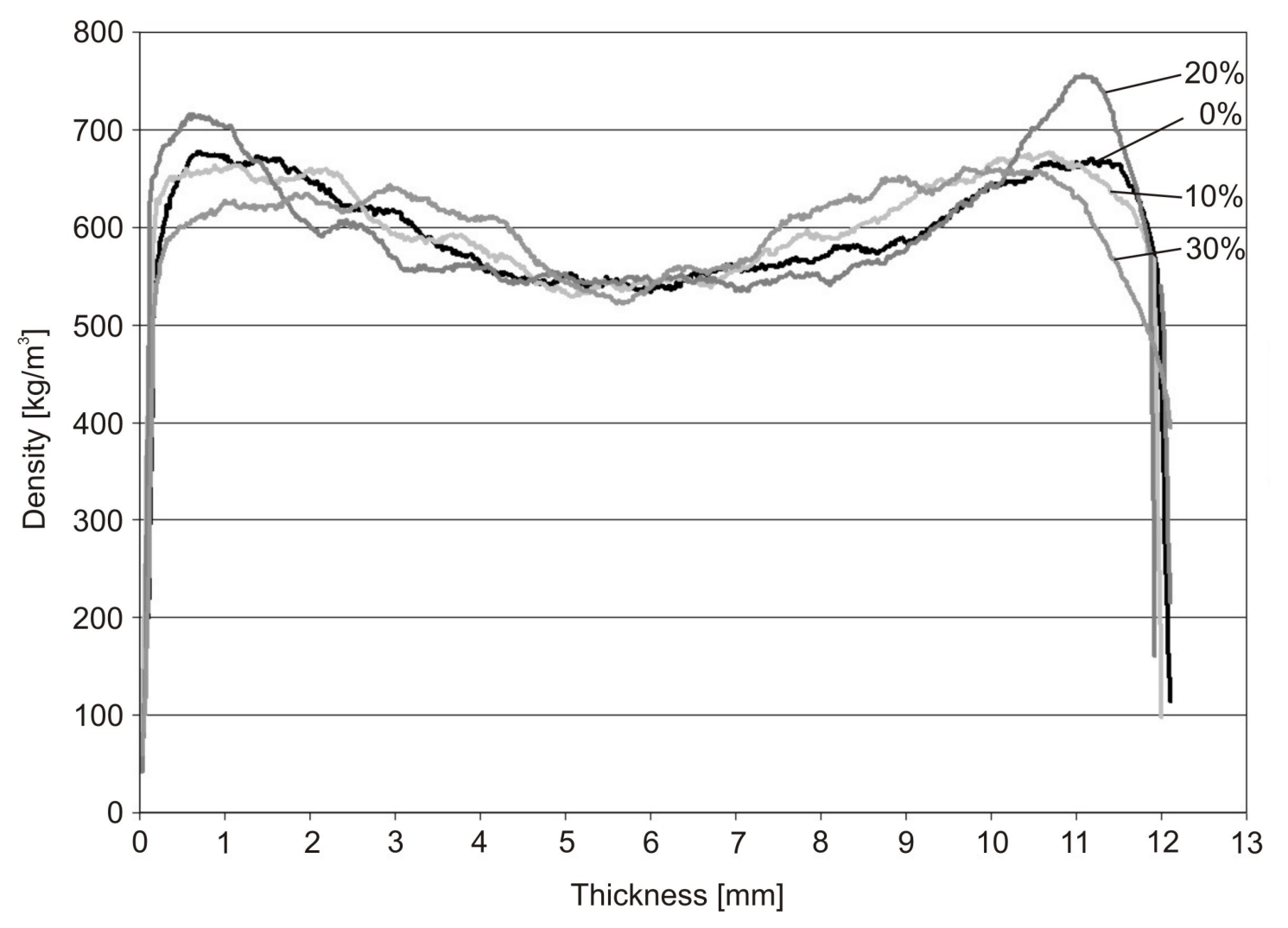

Fig. 1 